\title{
Polimer kompozitok állapotelemzése üveg fényvezető szállal és távközlési eszközökkel
}

\section{State monitoring of polymer composites with glass optical fibre and with equipment used in telecommunication}

\author{
Hegedűs Gergely, ${ }^{1}$ Czigány Tibor ${ }^{1,2}$ \\ ${ }^{1}$ Budapesti Müszaki és Gazdaságtudományi Egyetem, Gépészmérnöki Kar, Polimertechnika Tanszék, \\ Budapest, Magyarország \\ ${ }^{2}$ MTA-BME Kompozittechnológiai Kutatócsoport, Budapest, Magyarország, czigany@eik.bme.hu
}

\begin{abstract}
Thanks to the widespread use of optical fibers in telecommunication, they, and their accompanying equipment have become cost-effective and easily accessible. We have proved that the changed attenuation of a monomodal optical fiber built into a polymer composite can indicate the elongation of the structure compared to its original, unloaded state, before the optical fiber breaks. We also proved that the location of deformation in polymer composite structures can be found with OTDR equipment (used for checking the coupling of optical fibers).
\end{abstract}

Keywords: polymer composite, deformation monitoring, optical fiber, attenuation meter, OTDR.

\section{Összefoglalás}

A nagy mennyiségű felhasználásnak köszönhetően a távközlési fényvezető szálak és a hozzájuk kapcsolódó berendezések költséghatékonnyá és könnyen elérhetővé váltak. Célunk annak bemutatása, hogy a polimer kompozitba épített, egymódusú fényvezető szál megváltozott csillapításának mérésével következtetni lehet a szerkezet kezdeti, terhelésmentes állapotához képest bekövetkezett nyúlására, még a fényvezető szál szakadása előtt. Bizonyítottuk továbbá, hogy a polimer kompozit szerkezetekben létrejövő alakváltozások helye, helyei a távközlési hálózatok száltoldásainak ellenőrzésére használt OTDR-műszerrel kimutathatók.

Kulcsszavak: polimer kompozit, állapotelemzés, fényvezető szál, csillapításmérő, optikai visszaszórásmérő.

\section{Bevezetés}

A polimer kompozitok napjainkig töretlen fejlődésének köszönhetően egyre nagyobb szerepet kap az anyagi viselkedésük megismerésének szükségessége. Összetett szerkezetüknek köszönhetően viselkedésük szimulálása [1, 2] bonyolult feladat, amelynek figyelembe kell vennie a kompozitok különböző felépítési szintjeit, kezdve a nanoszintű anyagi összetevőktől, a mikroszintű alkotók (szál, mátrix) kapcsolatán keresztül egészen a makroszintű (rétegek) felépítésükig. Ennek köszönhetően nagy szerepet kap a kom- pozitok állapotának fizikai módszerekkel való megismerése, ellenőrzése roncsolásmentes, üzem közbeni (in-situ) módszerekkel [3]. Összetett szerkezetük lehetőséget nyújt állapotelemző szenzorok integrálására, amely nagymértékben növeli versenyképességüket más szerkezeti anyagokkal szemben [4]. Beépített optikai szenzorokkal meg lehet figyelni a kompozit teljes élettartama alatt (laminálás, térhálósodás, formából való kiemelés, összeszerelés, használat) bekövetkező alakváltozásokat, feszültségeket és az ebből eredő károsodásokat, hibákat. Az optikai szenzorok fényvezető 
szálában terjedő fény valamely jellemzője (teljesítménye, fázisa, polarizációja, hullámhossza, időzítése, spektrális eloszlása) megváltozik a külső körülmények hatására (mint például a szálat ért terhelés, deformáció) [5]. A különböző típusú optikai szenzorokban közös, hogy a jelfeldolgozó eszköz a fényvezető szálról leválasztható, külön egység, azt nem szükséges beépíteni [6]. Az optikai szenzorok alkalmazása laboratóriumi körülmények között egyre gyakoribb, de költségérzékeny iparágakban (pl. járműipar) nem terjedt el, mert viszonylag bonyolult, drága rendszer beépítését teszi szükségessé.

Az optikai szenzorok jelének közvetítésére az érzékelő- és feldolgozóegység között gyakran fényvezető szálat használnak. Napjainkban a fényvezető szálak és a hozzájuk kapcsolódó távközlési berendezések könnyen beszerezhetővé váltak. A távközlésben az optikai hálózatokban alkalmazott kötések (csatlakozások, hegesztések) állapotának vizsgálatára legáltalánosabban elterjedt eszköz az optikai beiktatásos csillapításmérő. A beiktatásos csillapításmérő műszer az optikai hálózat egyik végére csatlakoztatható meghatározott hullámhosszúságú (leggyakrabban 1310 és $1550 \mathrm{~nm}$ ) fényforrásból és a hálózat másik végére csatlakoztatható csillapításmérő egységből áll. A csillapítás $(\alpha(\lambda)[\mathrm{dB}])$ a szálba betáplált $\left(P_{b e}\right)$ és a szál kimenetén megjelenő $\left(P_{k i}\right)$ sugárzott teljesítmény hányadosa decibelben kifejezve [7] (1):

$$
\alpha(\lambda)=10 \cdot \lg \left(P_{b e} / P_{k i}\right)
$$

A csillapítás számításához szükséges sugárzott teljesítmény a sugárzás formájában kibocsátott, áteresztett vagy felfogott teljesítményt (watt) jelenti [8]. Az optikai hálózatok vizsgálatára használt további, általánosan elterjedt eszköz az optikai visszaszórásmérő műszer (OTDR optical time-domain reflectrometry), amely a Rayleigh-szórás jelenségéből adódó visszavert fényt használja. A Rayleigh-szórás a fényvezető szálban található mikroméretű egyenetlenségek miatt alakul ki. Az egyenetlenségek hatására a szálban a fényenergia egy része minden irányban szétszóródik. Minél közelebb van a fény hullámhossza a mikroméretű hibák nagyságához, annál nagyobb a szóródás mértéke. A szórt fény azon része, amely a fényvezető szál köpenyére a határszögnél nagyobb szögben érkezik, arról visszaverődik, és a szálon belül akár visszafelé terjed. A visszafelé terjedő fényt mérve információt kaphatunk az egyes szálszakaszok inhomogenitásáról vagy akár azok megváltozásáról. A mérőműszer fényimpul- zust küld a szálba, és figyeli az abból visszatérő fényt. A visszaérkező jel az idő múlásával egyre gyengül, ugyanis a fény egyre hosszabb utat tesz meg. Ismerve a fény terjedési sebességét, következtethetünk a visszaérkező jel kiindulási helyére. A Rayleigh-szórás segítségével lokalizálhatjuk a szálhegesztéseket, esetleges mikrohajlatokat, a csatlakozós kötéseket, szálhibákat, repedéseket, az esetleges töréseket és elágazásokat az optikai hálózaton belül. Az OTDR segítségével az egyes hibák helye a fényvezető szálon méteres nagyságrendű pontossággal meghatározhatók [9]. A mérés előnye, hogy az a fényvezető szál egyik végéről elvégezhető, hiszen a műszer a fényvezető szálból visszaverődő impulzusokat méri.

Többen kimutatták, hogy a fényvezető szálak mikro- és makroszintű hajlítása megjelenik a szálon átvitt fény teljesítményében [10-12]. Többen vizsgálták a kompozit összetett szerkezetének állapotát beépített fényvezető szálak segítségével, és eredményeik alapján a kompozit sérüléséből eredő szálroncsolódás miatt a fényvezető szál végén kilépő fény teljesítményének csökkenése felhasználható a károsodás helyének kimutatására [13-15]. Ebben az esetben a módszer megfelelő a károsodás helyének meghatározására, de a károsodás nagyságáról nem kapunk információt.

Korábbi munkáinkban [16, 17] már vizsgáltuk az üveg fényvezető szál felhasználhatóságát polimer kompozitok alakváltozásának kimutatására. Jelen munkánk keretein belül továbbra is a távközlésben elterjedt üveg fényvezető szálak és eszközök felhasználhatóságát vizsgáltuk polimer kompozit szerkezetek állapotelemzéséhez. Célunk volt a beépített fényvezető szálban terjedő fény megváltozott jellemzőjéből következtetni a kompozit kezdeti, terhelésmentes állapotához képesti változására, ismétlődő igénybevétel hatására. Ennek érdekében beépített fényvezető szálat tartalmazó kompozit próbatest kisfrekvenciás, lüktető húzóterhelésű fárasztása közben mértük a fényvezető szál csillapításának változását a távközlésben általánosan elterjedt optikai mérőmüszerek segítségével. Célunk volt az alakváltozás kimutatása a tönkremenetelt okozó, kritikus állapot előtt, és ehhez kapcsolódóan módszerünk továbbfejlesztése. Célunk volt annak bemutatása, hogy ha a megengedettnél nagyobb a szál csillapításának növekedése, tehát ha valahol a polimer kompozit károsodása miatt a fényvezető szál roncsolódott, egy külsőleg csatlakoztatott, a távközlésben elterjedt OTDR-műszer alkalmas lehet-e a hiba megtalálására. 


\section{Felhasznált anyagok, berendezések}

A kísérletekben felhasznált fényvezető szál G.652.D egymódusú, $125 \mu \mathrm{m}$ külső-, és $9 \mu \mathrm{m}$ magátmérőjű üvegszál (gyártó: Corning) volt, merőleges szálvég kialakítással.

Két réteg nulla és kilencven fokszövésű (ortotróp) előfeszített üvegszövet $\left(300 \pm 5 \% \mathrm{~g} / \mathrm{m}^{2}\right.$, RT $300 \mathrm{~N}$, Kelteks) rétegei közé $140 \mathrm{~mm}$ hosszan befüzött, összesen 3 m hosszú fényvezető szállal próbatestet készítettünk, úgy, hogy a fényvezető szálat a szakítógép befogópofái előtt kivezettük a próbatestből, így a szakítógép befogópofái a fényvezető szálat közvetlenül nem terhelték. A fényvezető szál a kompozitból való kilépési és belépési pontnál nagyon sérülékenynek bizonyult, mert a kézi laminálás után a szál környékét körbeölelő gyanta a szálat nagyon merevvé tette, és az könnyen eltört, ezért a szál mechanikai védelméül szolgáló, $250 \mu \mathrm{m}$-es lakkréteget csak középen, 100 mmes szakaszon távolítottuk el kábelcsupaszító fogóval, így a beépített fényvezető szálon oldalanként 20-20 mm lakkos szakasz beépítve maradt. A beépített fényvezető szál után (140 mm-en túl) a próbatestet további erősítőszövettel megerősítettük befogófülként, és a mérés kiértékelésénél a deformálódó próbatest eredeti hosszát 140 mmrel számoltuk. A próbatesteket nem darabonként alakítottuk ki, hanem többet, egyetlen lemezként, kézzel lamináltuk (így a kézi laminálás alatt a szövetrétegeket előfeszítve rögzíteni lehetett, és azok nem gyürődtek a mátrixanyag felhordása miatt), majd a laminált lemezből a próbatesteket kivágtuk. Mátrixanyagként telítetlen poliésztergyantát
(AROPOL M105 TB, Ashland SpA) és 1,5\% iniciátort (PROMOX P200TX, PROMOX SRL) alkalmaztunk, majd szobahőmérsékleten történő, 24 órás térhálósítás után a lemezből a próbatesteket kivágtuk. A próbatest $25 \mathrm{~mm}$ széles, $1,3 \mathrm{~mm}$ vastag, teljes hossza $250 \mathrm{~mm}$, befogási hossza $195 \mathrm{~mm}$, a fényvezető szál beépített hossza $140 \mathrm{~mm}$ volt. Minden vizsgálathoz 3 próbatest készült.

A fényvezető szál toldására száltörőt (Fujikura, CT-30) és szálhegesztő berendezést (Fujikura, FSM 12 S) használtunk. A fényvezető szál egyik végénél 1550 nm hullámhosszúságú fényt csatoltunk be (AFL Telecommunications, FlexScan FS-200 fényforrásból), és a másik végén $0,01 \mathrm{~dB}$ felbontású csillapításmérő és egyben OTDR-müszerrel (AFL Telecommunications, FLX380-304 FlexTester OTDR) vizsgáltuk a szál csillapításának változását.

A fényvezető szálat és a kompozit próbatesteket szakítógépben (Zwick, BZ050/TH3A) terheltük, és a keresztfej-elmozdulásból számoltuk a nyúlást (a keresztfej-elmozdulás és a kezdeti befogási hossz hányadosaként). A csillapításmérő műszernek saját adatgyűjtője nincsen, de a kijelzőjén leolvasható az aktuális csillapításérték. Annak érdekében, hogy a mért elmozdulás és erőértékekhez ezen csillapításértékeket hozzá tudjuk rendelni, videón rögzítettük a szakítógép szoftvere által megjelenített értékeket és a csillapításmérő műszer kijelzőjét (1. ábra). E felvételek segítségével később egyértelműen hozzá lehetett rendelni a szakítógép által rögzített értékekhez a csillapításértékeket.

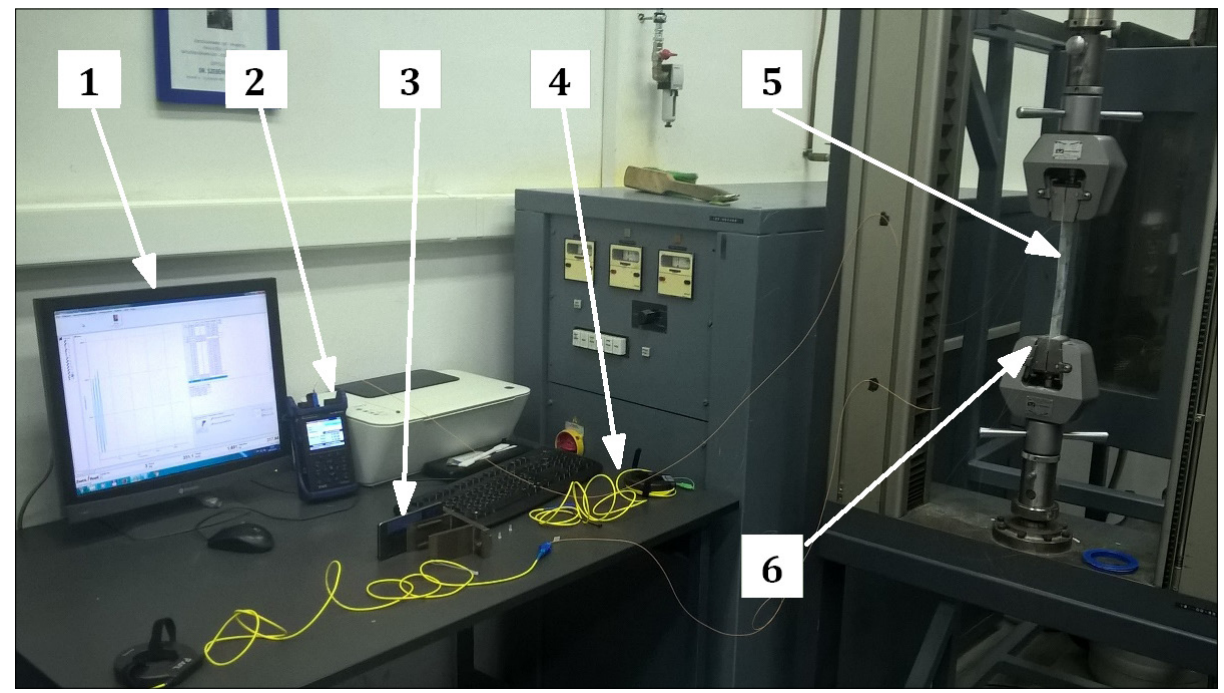

1. ábra. Mérési elrendezés (1 - szakítógép által mért értékek, 2 - csillapításmérö, 3 - videokamera, 4 -fényvezető szál, 5 - kompozit próbatest, 6 - szakítógép befogópofái) 


\section{Elvégzett vizsgálatok}

\subsection{Az ismétlődő, húzó igénybevétel hatása}

Nullkezdésü, ismétlődő húzás közben vizsgáltuk a szakítógépbe befogott próbatestbe épített fényvezető szál csillapításának változását három próbatesten. A próbatestekbe épített fényvezető szálak csillapításértéke a befogás után közel $0 \mathrm{~dB}$ volt. A vizsgálatoknál a fel- és leterhelés sebességét $1,5 \mathrm{~mm} / \mathrm{min}$-re állítottuk be, ciklusonként $0,1 \mathrm{~mm}$ növekvő elmozdulással. Egy próbatest esetében a mért értékeket a 2 . és 3 . ábra mutatja.

A diagramok alapján megállapítható, hogy a nyúlás és a fényvezető szál csillapításának változása összefügg, ami másodfokú függvénykapcsolattal leírható 94\%-nál nagyobb determinációs együttható mellett (3. ábra szaggatott vonalával jelölve). Ezek alapján elmondható, hogy a megváltozott csillapítás mérése alkalmas a nyúlás kimutatására.

A próbatestek mérési eredményei alapján a 4. ábra összesítve mutatja a csillapításváltozás értékeit a nyúlás függvényében.

A mérési eredmények alapján megállapítható, hogy a nyúlással szoros összefüggésben áll a fényvezető szál csillapítása. A megnyúlással növekszik a mért csillapítás. Bár nagy a szórása a mért csillapításértékeknek, elmondható, hogy $1 \%$ nyúlás fölött, 0,1 dB-nél nagyobb a fényvezető szál csillapításának változása. Ez nem tesz lehetővé pontos nyúlásmérést, de a megváltozott csillapítás segítségével a kompozitelem deformációs állapota kategorizálható: 0,1 dB csillapításváltozás alatt a kompozit megfelelő állapotban van, 0,1 dB csillapításváltozás fölött célszerü egyéb kiegészítő módszerrel az elem deformációs állapotát vizsgálni.

Az eddigi méréseknél 140 mm hosszú szálszakasz volt a próbatestekbe beépítve, és (ideális esetben) a beépített szakasz teljes egészében terhelődött. Következő kísérletsorozatunkkal a fényvezető szál egynél több terhelt szakaszának a hatását vizsgáltuk.

\subsection{Ismétlődő húzó igénybevétel hatása a fényvezető szál több terhelt szakaszán}

A fényvezető szál több terhelt szakaszának vizsgálatához $2 \mathrm{db}$ próbatestet egymás mellett fogtunk be a szakítógépbe, és a próbatesteket együtt húztuk (hasonló elrendezésben, mint az a 9. ábrán látható). A befogott próbatestekbe épített fényvezető szálakat, 10 m-es betétszállal, egymással összehegesztettük (a próbatesteket 1,5 + $1,5+10=13 \mathrm{~m}$ terheletlen fényvezető szál kötötte

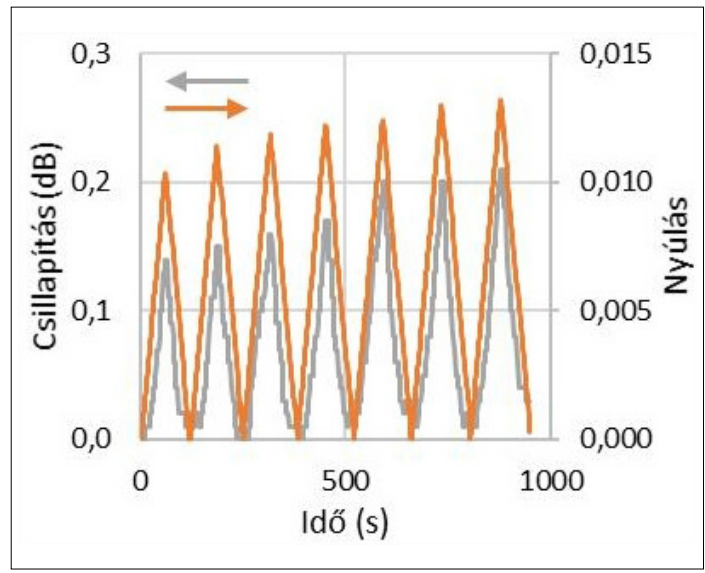

2. ábra. A csillapítás és a nyúlás változása az idő függvényében ismétlődő húzásnál

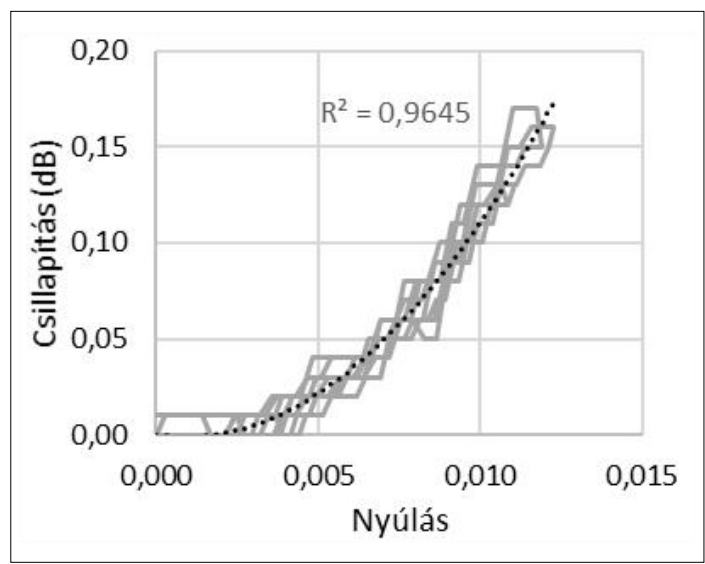

3. ábra. A csillapitás a nyúlás függvényében ismétlődő húzásnál

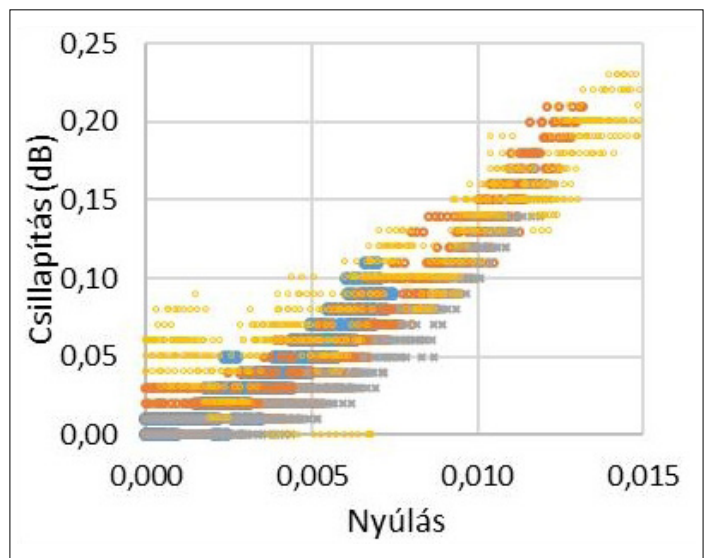

4. ábra. A próbatestek ismétlődő húzása során mért csillapításértékek a nyúlás függvényében (a különböző próbatesteknél mért értékek eltérő színnel jelölve) 


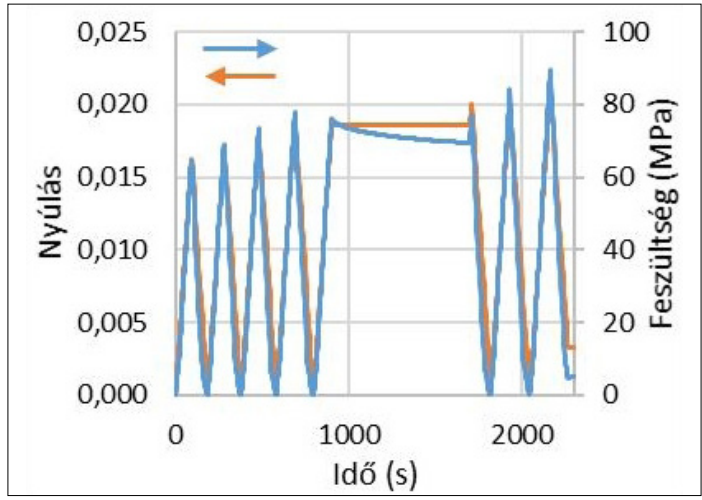

5. ábra. $2 \times 140 \mathrm{~mm}$ hosszúságú szakaszon terhelt, kompozitba épített fényvezető szál vizsgálata alatt mért nyúlás- és feszültségértékek az idő függvényében (jól azonosithatóan megjelenik az ábrán a mérés megállítása az OTDR-rel történö vizsgálathoz)

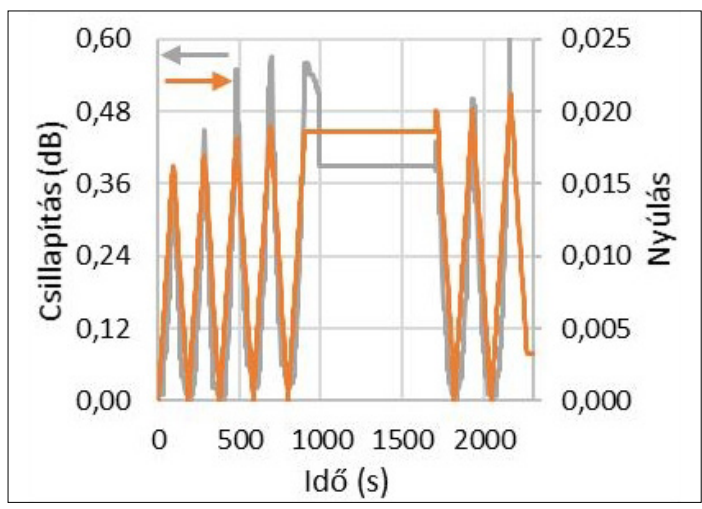

6. ábra. 2 × $140 \mathrm{~mm}$ hosszúságú szakaszon terhelt, kompozitba épített fényvezető szál vizsgálata alatt mért csillapítás- és nyúlásértékek az idő függvényében (jól azonosíthatóan megjelenik az ábrán a mérés megállítása az OTDR-rel történő vizsgálathoz)

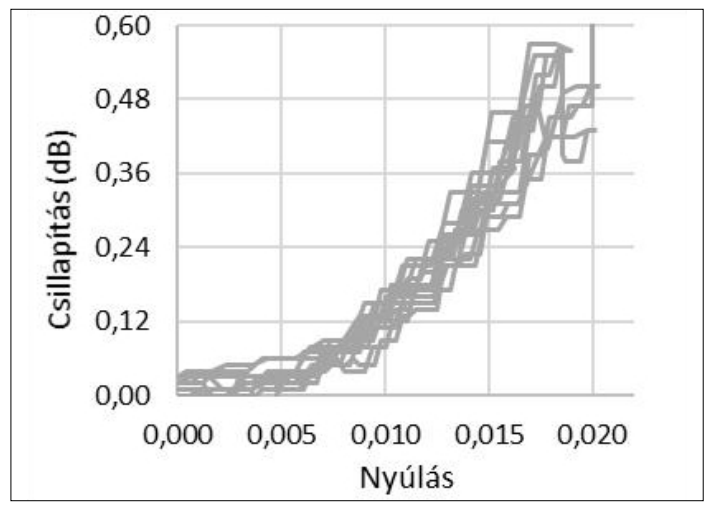

7. ábra. $2 \times 140$ mm-en terhelt fényvezető szál csillapításának változása a nyúlás függvényében össze), így végeredményben a szakítógépen tudtuk modellezni egy beépített fényvezető szál több ponton való terhelését. A terhelt fényvezető szál hossza $2 \times 140 \mathrm{~mm}$ volt. A fel- és leterhelést az előző kísérletsorozattal megegyezően, $1,5 \mathrm{~mm} / \mathrm{min}$ sebességgel végeztük, ciklusonként $0,2 \mathrm{~mm}$ növekvő max. elmozdulással. A mérést az 5 . ciklus közben megállítottuk, és a csillapításmérés helyett OTDR-műszert használtunk, amely mérés eredményét a 3.4. fejezetben mutatjuk be. Miután OTDR-műszerrel elvégeztük a vizsgálatot, a csillapításmérő műszert visszakötöttük a fényvezető szálra, és folytattuk a méréssorozatot. A 7. ciklusnál a beépített fényvezető szál elszakadt, és a csillapításmérő $40 \mathrm{~dB}$ fölötti értéket mutatott. Ekkor újra OTDR-múszert csatlakoztattunk rá, majd látható fénnyel is megvilágítottuk a fényvezető szálat, aminek eredményét a 3.3. fejezetben mutatjuk be. A méréssorozat alatt kapott értékeket az 5. és 6. ábra mutatja. A vizsgálat során mért csillapításértékeket a nyúlás függvényében a 7. ábra mutatja.

Az ábrán látható, hogy a fényvezető szál csillapítása nagyobb mértékben változik a nyúlás függvényében, mint az az előző kísérletsorozatoknál tapasztalható volt. Ennek oka egyértelműen a terhelt szálszakasz nagyobb hosszúsága. A fényvezető szál mindkét, 140 mm-es terhelt szakaszán jelentkezik csillapításváltozás, aminek összegét érzékeli a csillapításmérő műszer.

A mérés rámutat, hogy a terhelt szálszakasz hosszát ismernünk kell, hogy egyértelműen megállapítható legyen a fényvezető szál csillapításváltozása alapján a kompozit alkatrész vizsgált helyének deformációs állapota. Amennyiben egy fényvezető szálat több helyen is terhelünk, a csillapításmérő műszerrel nem lehet következtetni külön-külön a terhelések nagyságára. Amenynyiben a fényvezető szál környezetében fellépő nagymértékủ alakváltozás a szál tönkremenetelét okozza, az egyértelműen kimérhető a csillapításmérő műszerrel, de egyéb, kiegészítő eszközök szükségesek a tönkremenetel helyének megállapításához, amit a következőkben vizsgáltunk.

\subsection{A nagy deformáció helyének megállapí- tása látható fény segítségével}

A csillapításmérő műszerrel végzett kísérletek rámutatnak, hogy a kompozit nyúlásának hatására változik a beépített fényvezető szálak optikai csillapítása. A szálba becsatolt fény a szál nyúlásának köszönhetően elnyelődik, szóródik. A kompozit próbatest nagymértékű nyúlásakor a fényvezető szál el is szakadhat. A szál szakadása 


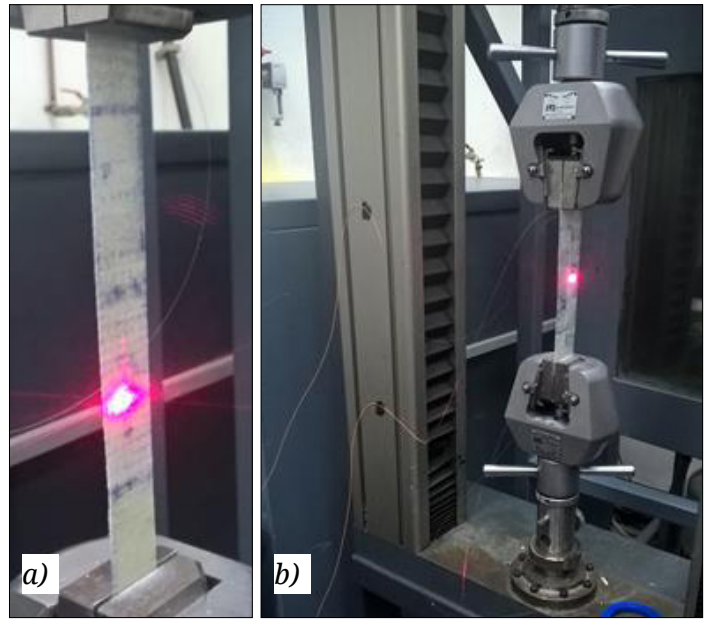

8. ábra. A szálszakadás helyén kilépő látható fény egy (a) és két (b) befogott próbatest esetén

esetén a tönkremenetel helyén a fény kilép a szálból. A csillapításmérő műszer megvilágítási hullámhossza az infravörös sugárzási tartományba esik, ezért ennek fénye szabad szemmel nem látható. A szálba becsatolt látható fény kilépése a szakadás helyén egyértelműen azonosítható, amely jelenség alkalmas lehet a károsodás helyének megállapítására (8. ábra).

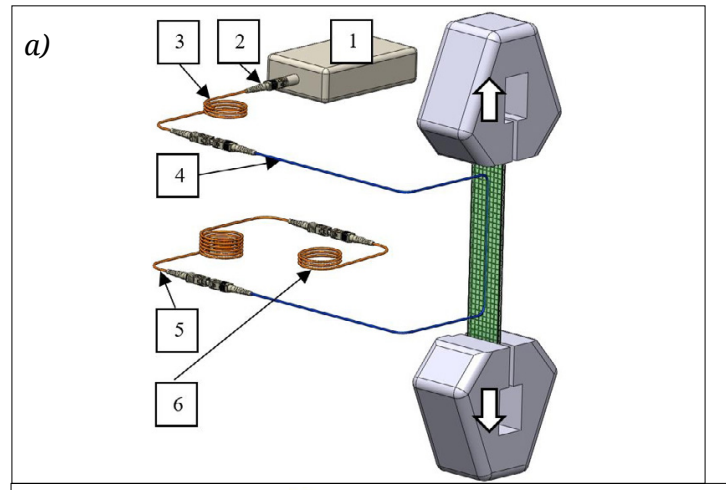

\subsection{A nagy deformáció helyének megállapí- tása OTDR-múszer segítségével}

Az eddigi mérések alapján elmondható, hogy a fényvezető szál környezetének alakváltozása a szál csillapításának változását eredményezi. Célunk volt megvizsgálni, hogy a távközlési hálózatok ellenőrzésénél is használt OTDR-müszer segítségével kimutatható-e a kompozitszerkezetben a nagy deformáció helye. Az általánosan elterjedt, kereskedelmi forgalomban lévő távközlési hálózatok vizsgálatára szolgáló OTDR-műszerek nem alkalmasak folyamatos megfigyelésre, mivel viszonylag hosszú idő szükséges a fényvezető szálba becsatolt, majd visszavert fény elemzéséhez és a mért paraméterek kiértékeléséhez. A módszer nem alkalmas kis időfelbontású, in-situ állapotellenőrzésre (a kiértékelés perces nagyságrendű), de megfelelő kiegészítője lehet a korábban bemutatott, csillapításméréses ellenőrzésnek egy időszakos állapotvizsgálatnál. A kompozitba épített fényvezető szálat vizsgálva a módszer alkalmas lehet a beépített szál környezetében jelentkező nagy deformációk érzékelésére és a deformáció helyének megállapítására. Ennek bizonyítása érdekében, amikor a 3.1. fejezetben bemutatott húzóterhelés alatti próbatestbe épített fényvezető szál csillapításában a csillapításmérő műszer nagy ugrást mutatott (1 dB fölöttit, minden esetben 0,8\%-nál nagyobb nyúlásnál), akkor a szakítógép keresztfejének mozgását megállítottuk, és a csillapításmérő műszer helyett a befogott kompozit próbatestbe épített fényvezető szál kivezetését - a 9. ábra szerinti mérési elrendezéssel az OTDR-műszerhez újracsatlakoztattuk.

Az OTDR-műszer holttere miatt a müszer után $150 \mathrm{~m}$ fényvezető szálat kapcsoltunk, és a kompozit próbatestbe épített fényvezető szálnak a próbatestből kilépő, kb. 1,5 m hosszú végét ehhez csatoltuk mechanikus optikai csatlakozóval.

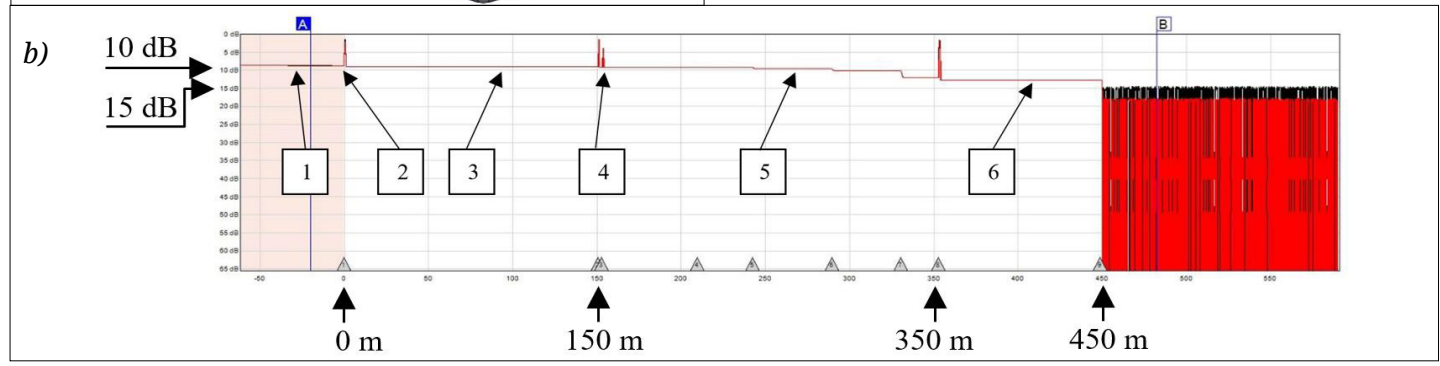

9. ábra. OTDR-es mérési elrendezés (a) és az OTDR-es mérés terheletlen próbatesten (b) (1-OTDR-müszer beépített előtétszállal, 2 - optikai csatlakozó, 3 - 150 m hosszú előtétszál, 4 - próbatestbe épített, $3 \mathrm{~m}$ hosszú szálszakasz, 5 - 200 m hosszú utótétszál, 6 - kis sugárral feltekert, 100 m hosszú szál a visszaverödés kiküszöbölésére) 
A próbatestbe épített fényvezető szálnak a próbatestből kilépő másik, kb. 1,5 m hosszú szálvégére - a szál végéről visszaverődő zavaró hatás elkerülése érdekében - mechanikus optikai csatlakozók segítségével kb. 200 m hosszú fényvezető szálat, majd ezután további, 100 m hosszú, kis sugárral feltekert fényvezető szálat kapcsoltunk. A műszerrel $1310 \mathrm{~nm}$ és $1550 \mathrm{~nm}$ hullámhosszon is megvizsgáltuk a szál hossza mentén a csillapítását. Az OTDR-műszer a csillapításbeli egyes ugrások helyét és értékét azonosítja $0,1 \mathrm{~m}$ és $0,01 \mathrm{~dB}$ pontossággal. Ezen ugrásokat a kiértékelőszoftver próbálja azonosítani az optikai hálózatokban használt elemekkel, szakadásokkal, amely kompozitok vizsgálatánál nem értelmezhető, de a hossz menti csillapításváltozás helye és értéke jól megfigyelhető. A terheletlen próbatesten mért OTDR-es csillapítás- és távolságértékeket a 9. ábra mutatja.

A 3.1. fejezetben bemutatott próbatest húzását $20 \mathrm{~dB}$ csillapításértéknél megállítottuk, és az előbb bemutatott módon rákapcsoltuk az OTDRműszert. A mért értékeket a 10. és 11. ábra mutatja.

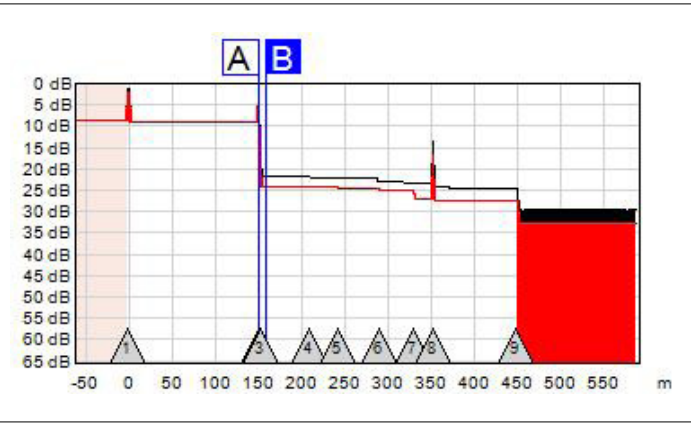

10. ábra. Az OTDR-müszer kiértékelőszoftvere az ábra alján jelölt számokkal azonosítja a csillapítási pontokat

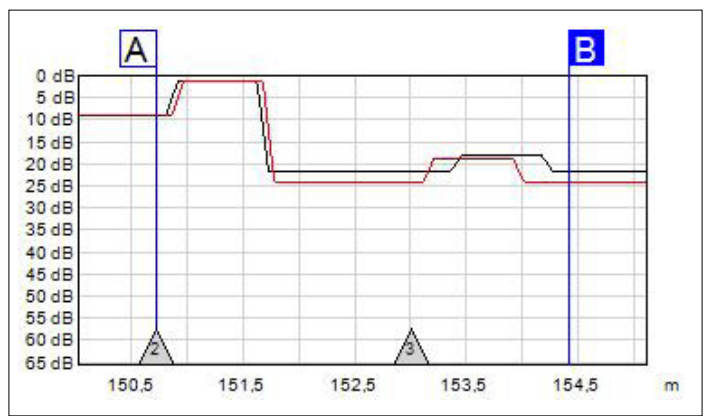

11. ábra. OTDR-es mérés diagramja a terhelt próbatestnél mérhető csillapításesésnél, a 10. ábra $A-B$ szakasza kinagyítva
A mérés eredményeként született grafikonból látható, hogy a próbatestbe épített fényvezető szálak végein a csatlakoztatásul szolgáló, 2 db optikai csatlakozó miatt megjelenő kiugrások között (a 11. ábra alján 2-es és 3-as számmal jelölve) a műszer igen nagy csillapításnövekedést mért. Ezt a növekedést a próbatestbe épített szálra ható terhelés miatt létrejövő csillapításváltozás okozza. Az OTDR-műszer 150 és 153 m között 150,7 m-nél 1310 nm-en 15,2 dB, 1550 nm-en 12,8 dB csillapítást mért. A várttal ellentétben a grafikonon a mechanikus optikai csatlakozó által keltett kiugrástól a próbatestben ébredő csillapításváltozás nem különül el, ami az OTDR-mérés hátrányát mutatja. Az alkalmazott OTDR-műszerrel nem mutatható ki cm nagyságrendben a nagy csillapításváltozást okozó deformáció helye.

Kísérletet végeztünk 2 db próbatest együttes befogásával és húzásával is, hogy megfigyelhessük a több ponton terhelt fényvezető szál viselkedését és vizsgálatának lehetőségét OTDR-műszerrel. A mérés érdekében a két próbatest kilógó fényvezető szálvégeinek egyikét $10 \mathrm{~m}$-es betétszállal összehegesztettük (a próbatesteket így 1,5 + 1,5 + 10 = 13 m terheletlen fényvezető szál kötötte öszsze), és a két próbatestet együttesen fogtuk be a szakítógépbe. A kísérleti elrendezést és a mérések eredményét a 12., 13. és 14. ábra mutatja.

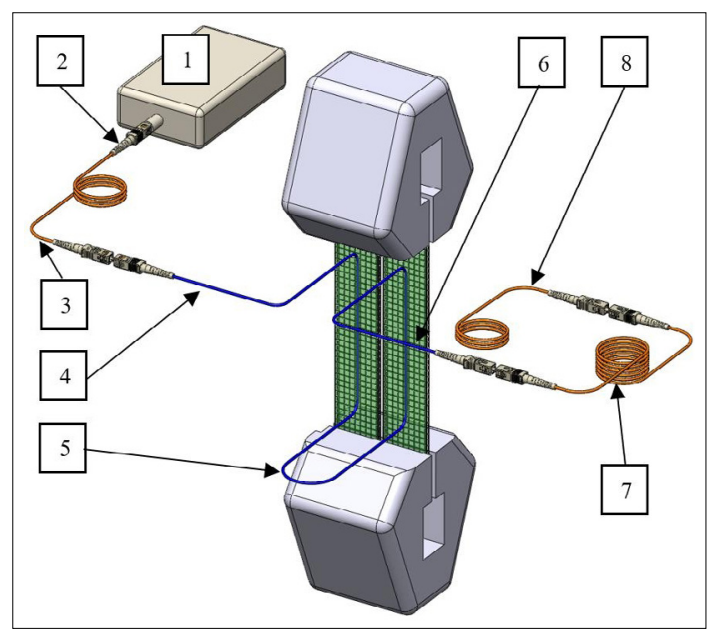

12. ábra. Kísérleti elrendezés két befogott próbatesttel (1 - OTDR-müszer, 2 - optikai csatlakozó, 3 - 150 m hosszú előtétszál, 4 - próbatestbe vezető, 1,5 m hosszú szálszakasz, 5 - próbatesteket összekötő, 13 m-es szálszakasz, 6 próbatestből kilépő, 1,5 m-es szálszakasz, 7 - 200 m hosszú utótétszál, 8 - kis sugárral feltekert, 100 m hosszú szál a visszaverődés kiküszöbölésére) 


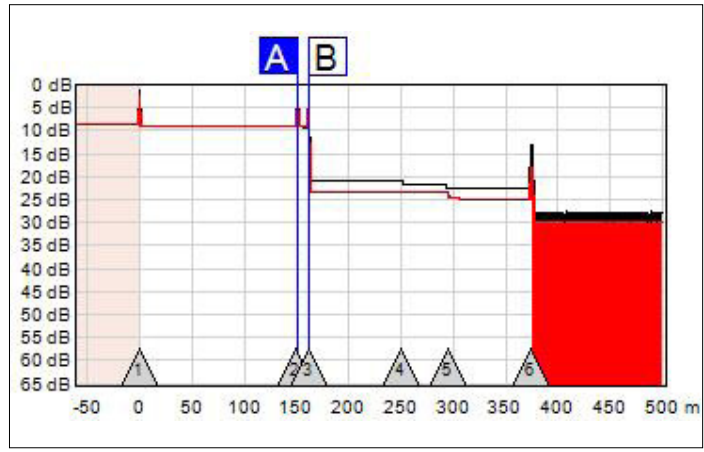

13. ábra. A két befogott próbatestben terhelt szál OTDR-es mérési grafikonja

A műszer szoftvere által kirajzolt grafikonon már csak két kiugró csúcs jelenik meg, és ezek sem azonos csillapításváltozást mutatnak. A müszer optikai hálózatokhoz kifejlesztett jellege ennél a mérésnél jól megmutatkozik. A műszer ebben az esetben már nem volt képes megkülönböztetni a mechanikus optikai csatlakozókat, azokat már nem is jelenítette meg a grafikonon, és az egyes pontokban mért csillapításváltozást sem volt képes megfelelően értékelni. A műszer az „A” jelzővonallal jelölt helyen, $1310 \mathrm{~nm}$-en 15,6 dB csillapítást mért, de a grafikonon ezt nem jelölte. Ezen a hosszon a valóságban az egyik terhelt próbatest beépített fényvezető szála volt, és a próbatest húzásának hatására létrejövő csillapításváltozást azonosította 15,6 dB-lel. A „B” jelzésnél az eszköz, 1310 nm-en, 162,0 m-nél 14,3 dB csillapítást mért, és ezt már meg is jelenítette a grafikonon.

A mérés rámutatott arra, hogy a műszer képes érzékelni és megkülönböztetni egyetlen fényvezető szál több terhelt szakaszát is, azok csillapításváltozását és néhány deciméteres pontossággal a helyüket, azonban a kifejezetten az optikai hálózatok minőségének értékelésére kifejlesztett szoftver ezeket a szakaszokat tévesen azonosíthatja, ezért megfelelő körültekintéssel kell eljárni az eredmények kiértékelésénél.

\section{Következtetések}

Bár eredetileg a csillapításmérő és az OTDR-műszer a távközlési optikai hálózatokban lévő szakadások, toldások minőségének és helyének ellenőrzésére szolgál, de általánosabb célú, a polimer mátrixú kompozit alapanyagból készített termékeknél a bemutatott eljárás alkalmas lehet egy olcsó, a kritikus tönkremenetel előtt a jelen lévő deformációt kimutató, in-situ állapot ellenőrzésre. A módszer költséghatékonyságát az alkalmazott

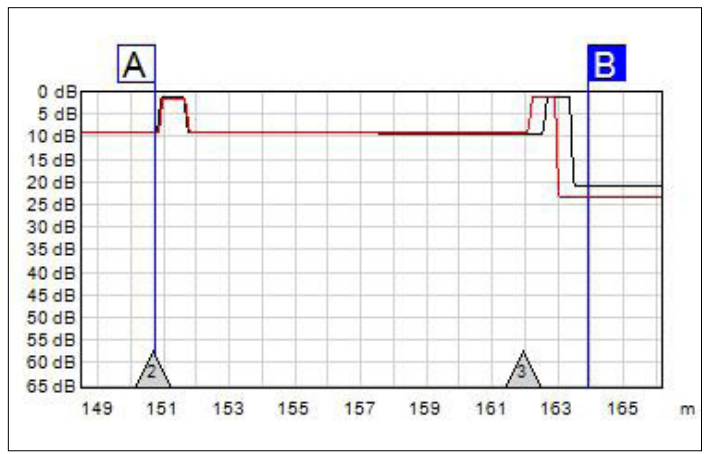

14. ábra. A két befogott próbatestben terhelt szál mérési grafikonjának egy részlete kinagyítva

eszközök biztosítják, hiszen mind az üveg fényvezető szál, mind az optikai beiktatásos csillapításmérő műszer egy könnyen elérhető, napjainkban elterjedt eszköz.

Eredményeink alapján látható, hogy a károsodást nem okozó nyúlással arányosan változik a polimer kompozitba épített egymódusú fényvezető szál csillapítása, és a terhelés megszűnte után a csillapítása visszaáll a kezdeti, terheletlen értékre. A módszer képes a károsodást okozó megnyúlás elérése előtt jelzéssel szolgálni a szerkezet 1\% fölötti nyúlására. A kompozitba épített üveg fényvezető szál terhelt hosszának ismeretében, annak csillapításváltozása alapján a megnyújtott szerkezet nyúlási állapota kategorizálható: megfelelő/ kiegészítő vizsgálatra szorul. Adott hosszúságú beépített fényvezető szálszakasz esetén meghatározható az a maximális csillapításváltozás, amelynél a kompozit nyúlása nem haladja meg az 1\%-ot, míg nagyobb csillapításváltozás esetén a kompozit nyúlását célszerű kiegészítő méréssel vizsgálni. A csillapításváltozás oka, hogy a fényvezető szál adhéziósan kapcsolódik a mátrixhoz, és így a kompozit alkatrész nyúlásával a fényvezető szál is nyúlik, ami miatt csökken a szál fényáteresztő képessége, azaz növekedik a csillapítása.

Bemutattuk, hogy a kompozit próbatestbe épített fényvezető szál deformáció miatt létrejövő csillapításváltozása OTDR-müszerrel is azonosítható. Az OTDR-műszer nem alkalmas in-situ elemzésre, de a csillapításmérővel végzett méréseket alkalmasan egészítheti ki. A műszer segítségével félméteres pontossággal megállapítható a fényvezető szálon belül a nagy csillapításváltozást okozó deformáció helye, illetve e deformációk helyei. A különbözően deformált helyek egymástól akkor különíthetők el, ha közöttük megfelelő hosszúságú ( 3 m) terheletlen szakasz van, mert különben a mérőműszer nem képes különválasztani őket. 


\section{Köszönetnyilvánítás}

A kutatást a Nemzeti Kutatási, Fejlesztési és Innovációs Hivatal (NKFIH) NVKP (NVKP_16-1-2016-0046), OTKA (K 116070 és K120592) és TÉT (2017-2.2.4-TÉTAT), illetve az Emberi Erőforrások Minisztériuma BME FIKP-NANO és a Nemzeti Kutatási, Fejlesztési és Innovációs Alap (NKFIA) TKP (TUDFO/51757/2019-ITM) pályázatai támogatták.

A szerzők köszönetet mondanak Nagy Andrásnak, Dobos Péternek és Szabó Zsoltnak (ATL Kft.) a mérések elvégzésében nyújtott segítségükért.

\section{Szakirodalmi hivatkozások}

[1] Kovács L., Romhány G.: Derivation of ply specific stiffness parameters of fiber reinforced polymer laminates via inverse solution of classical laminate theory. Periodica Polytechnica Mechanical Engineering, 62. (2018) 158-164. https://doi.org/10.3311/PPme.11846

[2] Maamar D., Zenasni R.: Optimization of Safety Factor by Genetic Algorithm of Circular Notched Carbon / Epoxy Laminate at Low Velocity Impact. Periodica Polytechnica Mechanical Engineering, 62. (2018) 218-225.

https://doi.org/10.3311/PPme.12041

[3] Sethy D., Makireddi S., Varghese F. V., Balasubramaniam K.: Piezoresistive behaviour of graphene nanoplatelet (GNP)/PMMA spray coated sensors on a polymer matrix composite beam. Express Polymer Letters, 13/11. (2019) 1018-1025.

https://doi.org/10.3144/expresspolymlett.2019.88

[4] Krawczak P.: Polymer composites: Evolve towards multifunctionality or perish. Express Polymer Letters, 13/9. (2019) 771.

https://doi.org/10.3144/expresspolymlett.2019.65

[5] Konstantopoulos S., Fauster E., Schledjewski R.: Monitoring the production of FRP composites: A review of in-line sensing methods. Express Polymer Letters, 8/11. (2014) 823-840.

https://doi.org/10.3144/expresspolymlett.2014.84

[6] Glisic B., Inaudi D.: Fibre optic methods for structural healt monitoring. John Wiley \& Sons Ltd., New York, 2007.

[7] Grattan K. T. V., Meggitt B. T.: Optical fiber sensor technology. Springer Science+Business Media, B.V, Dordrecht, 1995.
[8] MSZ 9620-1:1990: Fénytechnikai terminológia. A sugárzás alapfogalmai, mennyiségei és egységei.

[9] Elliott B., Gilmore M.: Fiber Optic cabling. Newnes, Oxford, 2002.

[10] Chinpon A., Thamaphat K., Hansuparnusorn M., Limsuwan P.: A force measurement method using the optical fibre beam. Procedia Engineering, 32. (2012) 989-993.

https://doi.org/10.1016/j.proeng.2012.02.043

[11] Luo F., Liu J., Ma N., Morse T. F.: Fiber optic microbend sensor for distributed sensing application in the structural strain monitoring. Sensors and Actuators, A: Physical, 75/1. (1999) 41-44. https://doi.org/10.1016/S0924-4247(99)00043-6

[12] Hu H.-F., Sun S.-J., Lv R.-Q., Zhao Y.: Design and experiment of an optical fiber micro bend sensor for respiration monitoring. Sensors and Actuators, A: Physical, 251. (2016) 126-133.

https://doi.org/10.1016/j.sna.2016.10.013

[13] Crane R. M., Gagorik J.: Fiber optics for a damage assessment system for fiber reinforced plastic composite structures. Quantitative NDE, 28. (1984) 1419-1430.

https://doi.org/10.1007/978-1-4613-3706-5_94

[14] Glossop N. D. W., Dubois S., Tsaw W., Leblanc M., Lymer J., Measures R. M., Tennyson R. C.: Optical fibre damage detection for an aircraft composite leading edge. Composites, 21/1. (1990) 71-80. https://doi.org/10.1016/0010-4361(90)90100-B

[15] LeBlanc M., Measures R. M.: Impact damage assessment in composite materials with embedded fibre-optic sensors. Composites Engineering, 2/5-7. (1992) 573-596.

https://doi.org/10.1016/0961-9526(92)90044-7

[16] Hegedűs G., Czigány T.: Developing a glass fibre sensor for polymer technology applications. Institute of Physics (IOP) Conference Series: Materials Science and Engineering, 426. (2018) 012015. https://doi.org/10.1088/1757-899X/426/1/012015

[17] Hegedűs G., Czigány T.: Analysis of the applicability of optical fibers as sensors for the structural health monitoring of polymer composites: the relationship between attenuation and the deformation of the fiber. Sensors and Actuators A: Physical, 272. (2018) 206-211. https://doi.org/10.1016/j.sna.2018.01.039 